Proc. Indian Acad. Sci. (Earth Planet. Sa.), Vol. 90, Number 1, March 1981, pp. 91-103. (C) Printed in India.

\title{
Magnetic, chemical and $x$-ray studies of magnetites from Tamil Nadu, India
}

\author{
N SUBBA REDDY and C V R K PRASAD \\ Dejartment of Geology, S.V. University, Tirupati 517502 , India
}

MS received 4 August 1980 ; revised 20 December 1980

\begin{abstract}
Natural intensity, susceptibility, and Koenigsberger ratio ware determined and studies of Rayleigh loops, and high field hysteresis, and variation of susceptibility with temperature from $-196^{\circ} \mathrm{C}$ to Curie temperature wire made on a number of magnetite-quartzite and pyroxene granulite sampl:s from Tamil Nadu. $\mathrm{FeO}, \mathrm{Fe}_{2} \mathrm{O}_{3}$, and $\mathrm{TiO}_{2}$ proportions were estimated and cell dimensions were determined. Frem the magnetic studies it is inferred that in general the samples contain predominantly multidomain grains. In a few cases single-domain particles are detected, while in a few other samples a mixture of superparamagnetic particles and single domain states could bo inferred. The relative remanence ratio is found to increase with coercive force. The ferromagnetic mineral in magnotito-quartzites is pure magnetite with a little alteration to hematite while in pyroxene granulites it is a titaniferous magnetite with a small percentage of $\mathrm{TiO}_{2}$. It is probable that the cell dimensions are dependent on oxidation in magnetites, and on the content of $\mathrm{TiO}_{2}$ in titaniferous magnetites.
\end{abstract}

Keywords. Magnetic pro,erties; magnetite; titaniferous magnetitc; oxidation; cell dimension; $\mathbf{x}$-ray studies; chemical studies.

\section{Intraduction}

In Tamil Nadu there are several occurrences of iron formations which are commonly referred to as magnetite-quartzites. These occur in the procambrian high grade granulite terrain of peninsular India. Important occurrences are in Kanjamalai, Godumalai, Nainaramalai, Thirthamalai and Kavuthimalai-Vediappanimalai areas. The associated rocks are generally various types of granulites and gneisses, dunites, peridotites, pegmatites and dolerite dykes. Pyroxene granulites are the most intimatcly associated rocks with the magnetite-quartzites. A study of mineralogy and chemical composition of the magnetites and the magnetic properties of the magnetite-quartzites and pyroxene granulites is presented here, to find the nature of the magnetic minerals, magnetic granulometry and the dependence of the magnetic properties. Although similar studies have been made mostly on igneous rock bodies (Radhakrishnamurthy et al 1978; Deutsch 
and Patzold 1976; Davis and Evans 1976) and recently on charnockites (Ramaswamy and Ramamurthy 1980) such studies are lacking on the magnetitequartzites.

\section{Experimental mothads}

A collection of 141 samples of magnetite-quartzites and 25 samples of the associated pyroxene-granulites was made. The magnetic properties of these samples were studied to determine the magnetic granulometry. Proportions of $\mathrm{FeO}, \mathrm{Fe}_{2} \mathrm{O}_{3}$, and $\mathrm{TiO}_{2}$, and cell dimensions of the separated magnetic concentrates were derermined.

Intensity of natural remanent magnetization $\left(J_{n}\right)$ and susceptibility $(k)$ in a field of 0.5 Oe were determined on all the samples, and the Koenigsberger ratios $\left(Q_{n}\right)$ were calculated. Rayleigh loops in a field of 100 and high-field hysteresis in a field of 2400 Oe were studied for all the samples. Representative samples of 16 magnetite-quartzites and 8 pyroxene granulites were studied for variation of susceptibility $(k)$, in a field of $0.5 \mathrm{Oe}$, with temperature $(T)$ from $-196^{\circ} \mathrm{C}$ to Curie temperature. Relative susceptibility $\left(k_{-188} / k_{25}\right)$ values were determined. Similarly the relative remanence ratios $\left(J_{r} / J_{m}\right)$ were also calculated.

Ferromagnetic concentrates from magnetite-quartzites and pyroxene granulites for chemical and $x$-ray analyses were obtained by crushing the samples to a fine powder in a gun metal mortar and the ferromagnetic fraction was separated by hand magnet and further purification and separation of silicates were carried out using Bromoform, Clerci solution, and acetone.

Total iron as $\mathrm{Fe}_{2} \mathrm{O}_{3}$ and $\mathrm{TiO}_{2}$ were determined calorimetrically, and $\mathrm{FeO}$ was determined by permanganometric method. These three constituents were determined in magnetic concentrates from selected samples of 38 magnetite-quartzites and 12 pyroxene granulites. Fourteen magnetic concentrates from magnetitequartzites and five concentrates from pyroxene granulites were subjected to $\mathbf{x}$-ray studies and their ceil dimensions were determined. These studies were carried out at the Indian Institute of Technology, Madras, and the Indian Institute of Science, Bangalore.

\section{Magnetic properties}

\section{1. $J_{*}, K, Q_{n}$ and Rayleigh loops}

The ranges of $J_{*}, K$ and $Q_{n}$ are given in table 1 and their distribution is shown in the figure $1 \mathrm{a}, \mathrm{b}$. There is general similarity of the histograms for all the three properties both for the magnetite-quartzites and pyroxene granulites. Such relationship indicates that the magnetic properties are dependent on the amount of ferromagnetic constituents.

A study of all samples for Rayleigh loops indicated that they generally show either a loop or line. All gradations in the thickness of the loop are found from a maximum as shown in figure $2 c$ to that of a line indicated in figure $2 a$. According to the criteria given by Radhakrishnamurty and Likhite (1970) the samples which show a loop may contain superparamagnetic (SP) particles while 

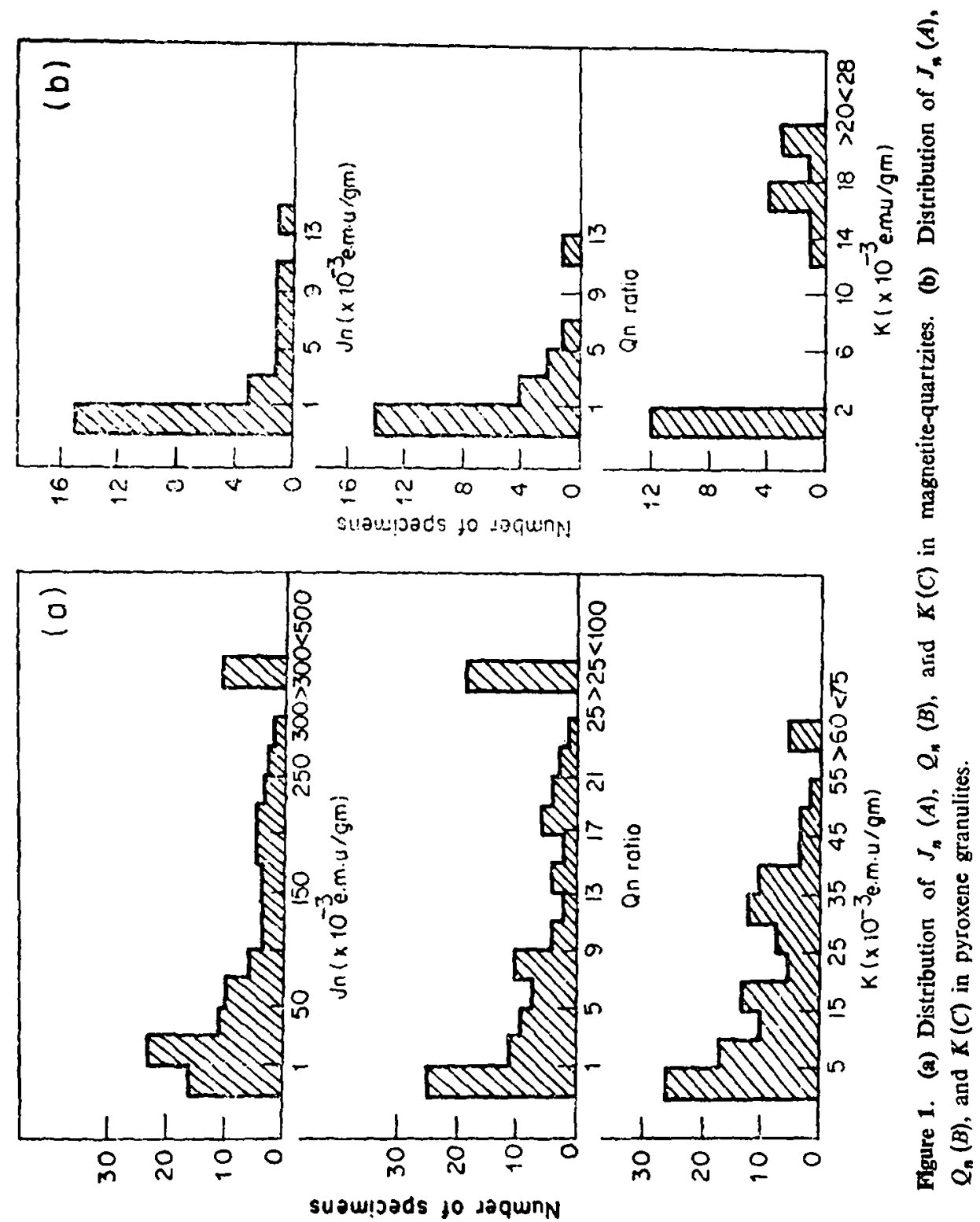
Table 1. Ranges of $J_{n}, K$ and $Q_{n}$.

\begin{tabular}{|c|c|c|c|c|c|c|}
\hline & \multicolumn{2}{|c|}{$J_{n} \times 10^{-3} \mathrm{emu} / \mathrm{g}$} & \multicolumn{2}{|c|}{$K \times 10^{-3} \mathrm{emu} / \mathrm{g}$} & \multicolumn{2}{|c|}{$Q_{n}$} \\
\hline & Minimum & Maximum & Minimum & Maximum & Minimum & Maximum \\
\hline $\begin{array}{l}\text { Magnetite- } \\
\text { quartzites }\end{array}$ & $0 \cdot 13$ & $561 \cdot 3$ & $0 \cdot 122$ & $73 \cdot 1$ & 0.05 & $100 \cdot 8$ \\
\hline $\begin{array}{l}\text { Pyroxene- } \\
\text { granulites }\end{array}$ & 0.01 & $11 \cdot 5$ & 0.013 & $26 \cdot 4$ & 0.033 & $11 \cdot 3$ \\
\hline Ranges of $J$ & , and $Q_{n}$ & & & & & \\
\hline
\end{tabular}

those which show a line may have multidomain (MD), single domain (SD), or cation deficient (CD) particles. In the case of two samples $K_{0}$ and $V_{15}$ a small constriction of the loop is observed (figure $2-b, K_{0}$ ). Radhakrishnamurty and Sastry (1970) and Deutsch and Patzold (1976) have attributed such constrictions to strong interaction in dense SP particle clusters. The relative susceptibility values are given in table 2 and range between 0.28 to 0.92 in the case of magnetite-quartzites and 0.39 to 1.13 for pyroxene granulites. The high values obtained for the granulite samples may suggest the presence of very fine particles which may be SP even at $-196^{\circ} \mathrm{C}$.

\section{2. $k$-T curves}

From a study of variation of $k$ with $T$ it is clear that all the samples are similar and indicate Curie temperatures ranging between $535^{\circ} \mathrm{C}$ and $580^{\circ} \mathrm{C}$. A representative $k-T$ curve is shown in figure 3. The range of Curie temperatures obtained generally indicate the presence of almost pure magnetite (Tanaka and Kono 1974). Though the Curie temperature decreases with increasing content of $\mathrm{TiO}_{2}$, the samples of the present study contain only negligible amounts of $\mathrm{TiO}_{2}$ and therefore it is probable that $\mathrm{TiO}_{2}$ content has no influence on the Curie temperatures of the samples. The presence of strains, imperfections and impurities in the magnetites may generally lower their Curie temperature (Tarling 1971).

The $k-T$ curves of the magnetite-quartzites are similar to those obtained by Radhakrishnamurty (1975), Radhakrishnamurty and Deutsch (1974), and Radhakrishnamurty et al $(1978,1979)$ for basalts containing MD grains. The characteristic sharp $k$-peak as shown in figure 3 , occurring in the temperature range of $-150^{\circ} \mathrm{C}$ to $-146^{\circ} \mathrm{C}$ though similar to that of basalts $\left(-165^{\circ} \mathrm{C}\right.$ to $\left.-150^{\circ} \mathrm{C}\right)$ is slightly higher which could be due to impurities in the samples. In the samples studied for $k-T$ curves the characteristics of maghaemite were not noticed.

\subsection{High field hysteresis}

The hysteresis loops in a field of 2400 Oe shown in $D, E$ and $F$ of figure 2 indicate that there are different types of loops. The $J_{r} / J_{m}$ values for magnetite- 

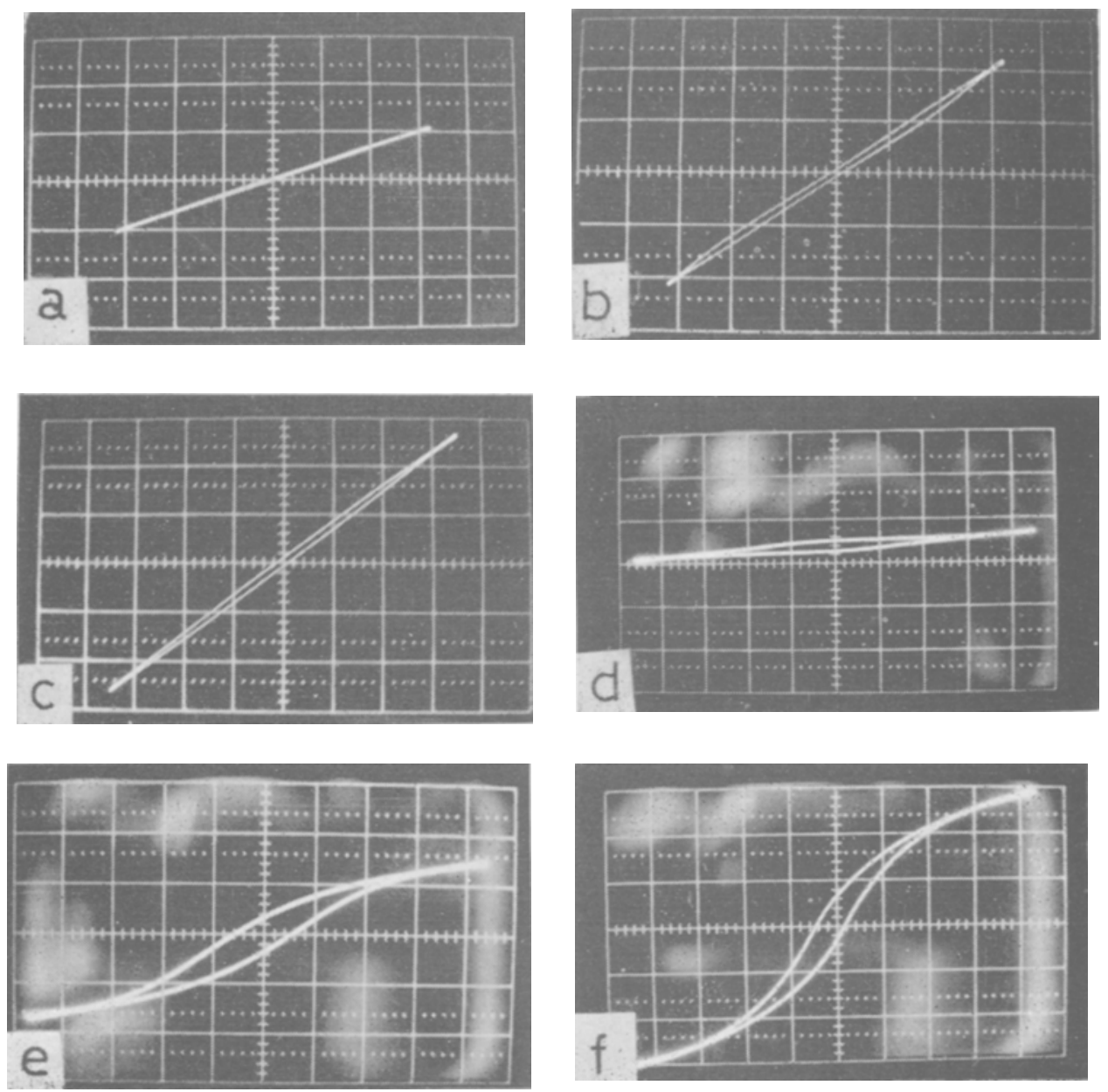

Figure 2. a, b, and c. Rayleigh loops at room temperature in a field of $10 \mathrm{O}$. a-almost line, $b$-constricted loop, c-loop.

Scale : Horizontal axism small division $=0.660$.

Vertical axis-1 small division $=17 \times 10^{-3} \mathrm{emu}$.

d, e and f. High field hysteresis loops at room temperature in a field of $2400 \theta$. Scale : Horizontal axis-1 small division $=570$.

Vertical axis-1 small division

$=$ Figure d. $1 \cdot 11125 \mathrm{emu}$

$=$ Figures $e$ and $f .2 \cdot 2225 \mathrm{emu}$. 


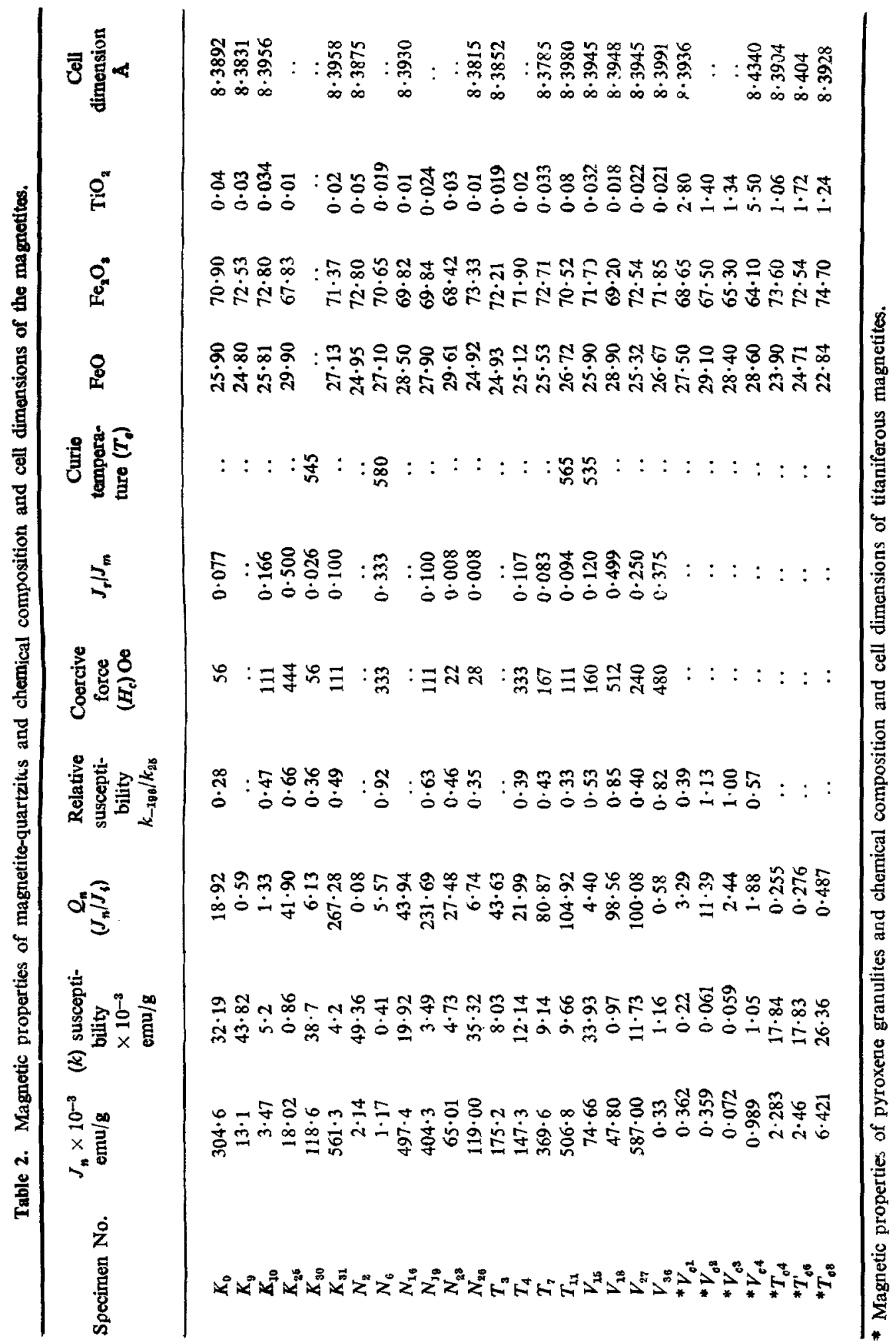




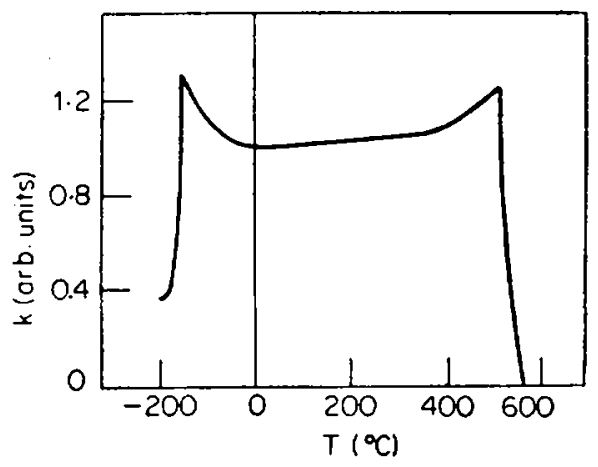

Figure 3. $k-t$ curve from $-196^{\circ} \mathrm{C}$ to Curie temperature.

quartzites (table 2) range between 0.008 and 0.50 . The high values of $J_{r} / J_{m}$ are generally associated with high $H_{\text {. }}$. The $J_{f} / J_{m}$ ratio is independent of anisotropy (Dunlop, 1972). According to Nagata (1961) there will be a general increase in $J_{r} / J_{m}$ with $H_{0}$ in igneous rocks. Such relationship is found in the magnetitequartzites which is shown in figure 4. The theoretical value of 0.5 for $J_{r} / J_{m}$ is expected for SD particles distributed in a nonmagnetic matrix (Dunlop 1972; Dunlop et al 1973; Deutsch and Patzold 1976). The increase in $H_{0}$ and saturation remanence reflects the increase in $J_{r} / J_{m}$ ratio as the fraction of singledomained regions increase (Kono 1977). From table 2 it can be seen that the samples $K_{2 j}$, and $V_{18}$ have a value of 0.5 for $J_{r} / J_{m}$ and these samples also exhibit the highest $H_{e}$ which probably indicates the presence of SD particles. A similar interpretation has been given by Day et al (1976). These samples give $Q_{n}$ values of 41.9 and 98.56 respectively. According to Radhakrishnamurty and Deutsch (1974) the value of $Q_{n}$ ranging between 10 and 100 indicates the presence of SD particles in basalts. Therefore the referred samples of magnetite-quartzites may contain SD particles. Radhakrishnamurty et al (1977) suggest the presence of MD grains if the $J_{r} / J_{m}$ is less than $0 \cdot 2$. In most cases of magnetite-quartzites the $J_{r} / J_{m}$ is less than $0 \cdot 2$ and it is probable that they contain mostly MD grains. In other cases where the $J_{n} / J_{m}$ value is above 0.2 but below 0.5 there may be a mixture of MD and SD grains. Similar interpretations have been given by Davis and Evans (1976).

\section{Chemical studies}

\subsection{Chemical studies}

The results of the chemical analysis are shown in table 2. The molecular percentages of the analyses are calculated and plotted in the $\mathrm{FcO}-\mathrm{Fe}_{2} \mathrm{O}_{8}-\mathrm{TiO}_{2}$ ternary diagram (figure 5A, after Akimoto and Katsura 1959). From the figure it can be seen that the ferromagnetic concentrates from magnetite-quartzites fall near the $\mathrm{Fe}_{3} \mathrm{O}_{4}$ point and on the line $\mathrm{Fe}_{3} \mathrm{O}_{4}-\mathrm{Fe}_{2} \mathrm{O}_{3}$. This indicates that the $\mathrm{TiO}_{2}$ in them is very small and mineralogically they are pure magnetites with a small proportion of haematite. The poverty of $\mathrm{TiO}_{2}$ in magnetites from metamorphic 


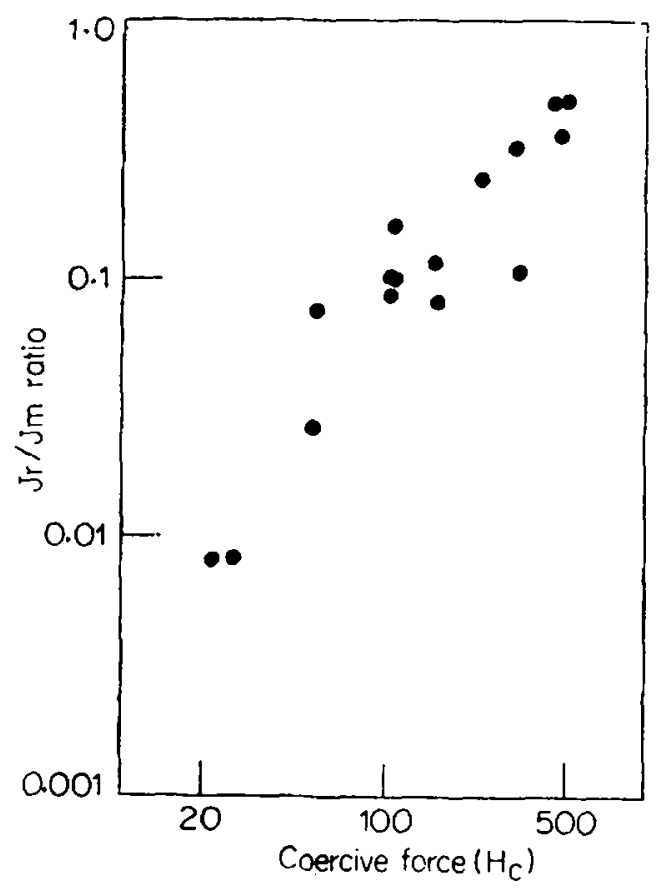

Figure 4. Relationship between relative remanence ratio $\left(J_{,} / J_{m}\right)$ and coercive force $\left(H_{0}\right)$ in magnetite quartzites.

rocks, as compared to those from most igneous rocks, was reported by Buddington et al (1955). Ore microscopic studies also indicate the presence of pure magnetite with some alteration to haematite. In the magnetites, which are hereafter referred as such, ilmenite lamellae have not been noticed. The small proportion of $\mathrm{TiO}_{2}$ present in the samples may not be in solid solution in magnetite. The ferromagnetic concentrates from pyroxene granulites fall near $\mathrm{Fe}_{3} \mathrm{O}_{4}$ point (figure 5A) but slightly higher than those of the concentrates from magnetitequartzites, because of the presence of $\mathrm{TiO}_{2}$ in higher proportions. Ore microscopic study of granulites indicated the presence of magnetite and ilmenite. The concentrates from granulites are referred to as titaniferous magnetites to distinguish them from the magnetites separated from magnetite-quartzites. The effect of differences in chemical composition of the samples is not reflected in magnetic properties since there is not much variation in the composition of magnetite or titaniferous magnetites.

The atomic ratio of $\mathrm{Fe} /(\mathrm{Fe}+\mathrm{Ti})$ and the atomic proportion of metals to oxygen calculated on the basis of 32 oxygen atoms $32 X(\mathrm{Fe}+\mathrm{Ti}) / 0$ are represented in figure 5B (after Akimoto and Katsura 1959) by taking the former on the abscissa and the later in the ordinate. The atomic ratio of $\mathrm{Fe} / \mathrm{Fe}+\mathrm{Ti}$ ranges from 0.9995 to 1.0000 for magnetites and from 0.9458 to 0.9907 for titaniferous magnetites. The value of $32 \times(\mathrm{Fe}+\mathrm{Ti}) / 0$ is a measure of the degrec of oxidation which is in the range between 23.37 and 23.96 for magnetites and varies from 23.14 to 23.82 in titaniferous magnetites. As can be seen from figure $5 \mathrm{~b}$ all points of 


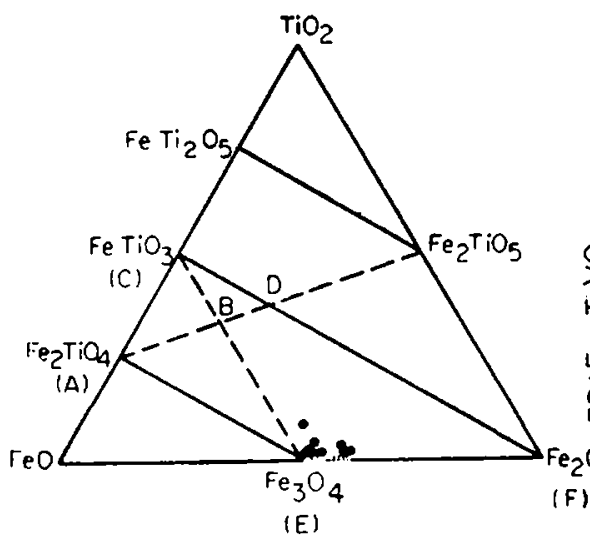

(0)

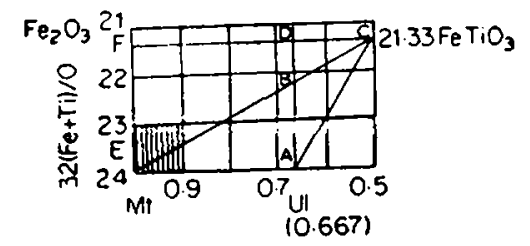

$\mathrm{Fe} / \mathrm{Fe}+\mathrm{Ti})$

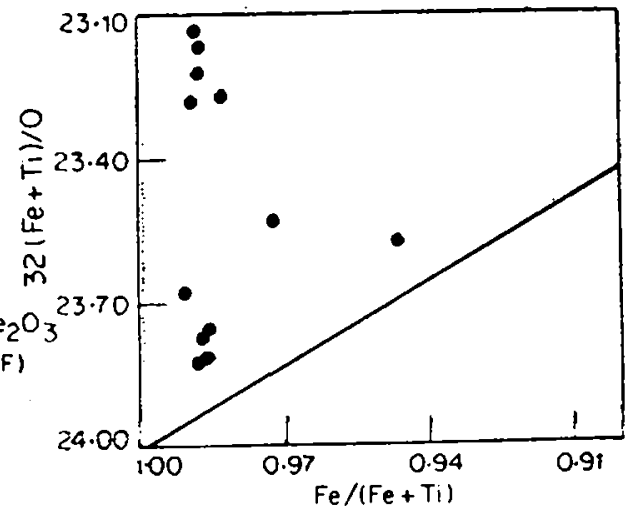

(b)

Figure 5. (a) $\mathrm{FeO}-\mathrm{Fe}_{2} \mathrm{O}_{3}-\mathrm{TiO}$, hernary diagram aftor Akimoto and Katsura, 1959. (·) Magnetite quartzites. (o) Pyroxene granulites. (b) Relation betwoen 32 ( $\mathrm{Fe}+\mathrm{Ti}) / \mathrm{O}$ and $\mathrm{Fe} /(\mathrm{Fe}+\mathrm{Ti})$. $\mathrm{Fe}$ includes $\mathrm{Fe}^{2+}$ and $\mathrm{Fe}^{2+}$. After Alimoto and Katsura 1959.

The bottom figure is an enlarged viow of the hatched portion of the top figure. (·) Magnetite (M) from magnetite quartzites. (O) Titaniferous magnetites (TM) from pyroxene granulites.

magnetites are distributed very close to EF line which suggests different degrees of oxidation from magnetite to haematite. All points of titaniferous magnetites fall above the line EBC indicating the absence of ulvospinel in solid solution and the presence of ilmenite.

From the weight percentages, normative minerals are recalculated. In the proportion of the normative minerals the percentage of haematite in the magnetites ranges from 1.36 to 18.64 and in titaniferous magnetites it varies between 3.63 and $26 \cdot 43$. The excess of haematite cannot be accounted by considering it to be in solid solution in magnetite. Greig et al (1935) and Edwards (1949) found that at $1075^{\circ} \mathrm{C}$ magnetite with $8 \% \mathrm{Fe}_{2} \mathrm{O}_{3}$ in solid solution is in equilibrium with haematite containing less than $0.5 \% \mathrm{Fe}_{2} \mathrm{O}_{4}$, and that at $1452^{\circ} \mathrm{C}$ the magnetite can contain $30 \% \mathrm{Fe}_{2} \mathrm{O}_{3}$ which on cooling separates out as haematite. It is therefore unlikely that excess of $\mathrm{Fe}_{8} \mathrm{O}_{8}$ occurs as solid solution in magnetites. Basta (1959) suggests that oxidation of natural magnetite results in the production of $\mathrm{Fe}_{8} \mathrm{O}_{8}$ (maghaemite) which is unstable at moderate to high temperatures and inverts to $a-\mathrm{Fe}_{2} \mathrm{O}_{3}$. For this reason he concludes that it is unlikely to occur in metamorphic rocks. Gjelsvik (1957) suggests that high $\mathrm{Fe}_{2} \mathrm{O}_{3}$ is certainly due to oxidation and confirms it by ore microscopic studies. According to Abdullah 
and Atherton (1964) the $\mathrm{Fe}_{2} \mathrm{O}_{3}$ surplus appears commonly in magnetites from metamorphic rocks and is often due to late oxidation or martitization or even due to the development of maghaemite and not due to the presence of solid solution, since the temperatures of the formation of metamorphic magnetites do not reach the high temperatures where solid solution may exist. Since the area from which the samples are collected belongs to the high grade granulite facies of the regional metamorphism (in which the temperatures may have reached to about $800^{\circ} \mathrm{C}$ to $900^{\circ} \mathrm{C}$ which are much lower than the temperatures where solid solution can exist) it is suggested that the greater or lesser amounts of excess $\mathrm{Fe}_{2} \mathrm{O}_{3}$ is due to varying degrees of oxidation without maghaemitization. X-ray diffraction studies, magnetic properties and ore microscopic studies revealed the absence of maghaemite.

\subsection{X-ray studies}

The cell dimensions determined are given in table 2, for magnetites ranging between $8 \cdot 3785 \AA$ to $8 \cdot 3991 \AA$. In the case of titaniferous magnetites the range is $8.3904 \AA$ to $8.4340 \AA$. The best known value of the cell dimension of pure natural magnetite, according to Basta (1957), is $8.3963 \pm 0.0005$ at $18^{\circ} \mathrm{C}$. The cell dimensions determined show deviations from the standard value. The dependence of cell dimension of the magnetite on the proportion of $\mathrm{TiO}_{2}$ and the oxidation state have been suggested by Basta $(1957,1959)$. Similar interpretations were given by Nagata (1961), and Stacey and Banerjee (1974). The TiO ${ }_{2}$ contents in the magnetites are very low. There is no effect of the presence of $\mathrm{TiO}_{2}$ on cell dimensions in magnetites whereas in the case of five samples of titaniferous magnetite there is a relationship of increasing cell dimension with increase in $\mathrm{TiO}_{2}$ content (figure 6). Of all the samples determined $V_{\text {ot }}$ has the highest cell size of $8 \cdot 4340 \AA$ which also has the highest content of $\mathrm{TiO}_{2} 5 \cdot 2 \%$. Ore microscopic examination has revealed the presence of magnetite with exsolution lamellae of ilmenite where as in the case of magnetite-quartzites the presence of ilmenite could not be noticed. Therefore the observed increase in cell sizes of the titaniferous magnetites from granulites is considered here as due to the presence of $\mathrm{TiO}_{2}$.

To test the dependence of the cell dimension on the oxidation in the case of magnetites the oxidation values [the atomic proportion of metals to oxygen calculated on the basis of 32 oxygen atoms $-32 \times(F e+T i) / 0]$ are plotted against cell dimensions in a graph (figure 6) which shows a general decrease of cell dimension with increasing oxidation. Oxidation parameters $(Z)$ of Ozima and Sakamoto (1971) were also calculated and they do not show any relationship with the cell dimensions.

Akimoto et al (1957), O'Reilly and Banerjee (1967), O'Reilly and Readman (1971), and Ozima and Sakamoto (1971) have conducted experiments on synthetic oxidized titanomagnetites with different mole fractions of $\mathrm{Fe}_{2} \mathrm{TiO}_{4}$ and studied the relationship existing between saturation magnetization, Curie temperature and cell dimensions. They have drawn the contours of equal Curie temperature, saturation magnetization, and cell dimensions in the $\mathrm{FeO}_{-}-\mathrm{Fe}_{2} \mathrm{O}_{3}-\mathrm{TiO}_{2}$ ternary diagram. The results obtained by them do not correlate with each other (Stacey and Banerjee 1974) and with the data on natural samples of the same composition, (Joshima 1973). The compositions of the samples cannot be plotted in either Ozima and Sakamoto, or O'Reilly and Readman diagrams since the compositional 


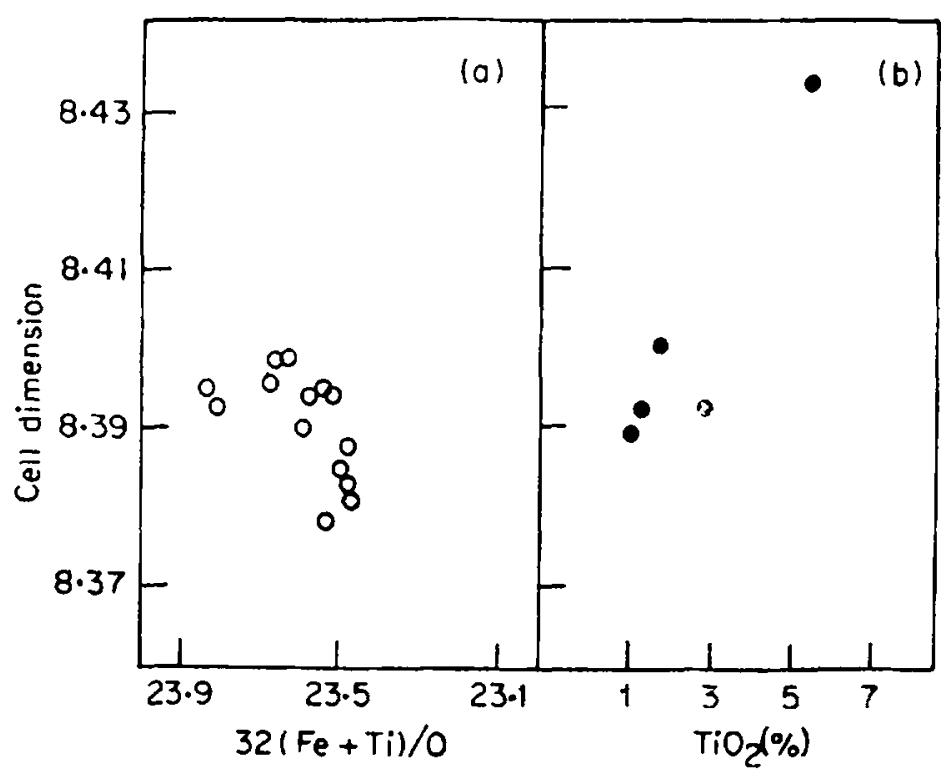

Figure 6. (a) Relationship between $32(\mathrm{Fe}-\mathrm{Ti}) / O$ and cell dimensions in magnetites separated froni magnetite quartzites. (b) Relationship between $\mathrm{TiO}_{2}$ per cent and cell dimension in titaniferous magnetites separated from pyzoxene of granulites.

range of their synthetic samples are widely different from the samples studied. If the plots of the chemical analyses of the samples of the present discussion are made in Akimato et al (1957) diagrams, they indicate Curie temperature of $580^{\circ} \mathrm{C}$ and cell dimension of $8.395 \AA$ for the magnetites. The Curie temperatures and cell dimensions obtained from the diagram do not correspond with the actual results obtained. This discrepancy may be due to the fact that Akimoto et al (1957) carried out the experiments on synthetic samples. Another possibiility is that the separated ferromagnetic minerals are not perfectly in single phase, but contain two or more phases which sannot be detected by $x$.ray diffraction or chemical analyses (Joshima 1973).

\section{Conclusions}

The observed magnetic properties are considered as due to the presence of mainly MD grains with a combination of SD and SP particles except in a few cases where SD particles may be dominant, while in few other samples a mixture of SP and SD states could be inferred. It is found that the $J_{n} / J_{m}$ ratio increases with increase in $H_{0 .}$ Magnetite from magnetite-quartzites is pure except for a little alteration to haematite. The excess of $\mathrm{Fe}_{2} \mathrm{O}_{3}$ in these is due to varying degrees of alteration but not due to the presence of $\mathrm{Fe}_{2} \mathrm{O}_{3}$ in solid solution. The cell dimensions are dependent on oxidation and $\mathrm{TjO}_{2}$ content. 


\section{Acknowledgements}

The authors are thankful to Dr C Radhakrishnamurty of Tata Institute of Fundamental Research, Bombay, for providing the data on susceptibility versus temperature studies and for going through the manuscript and offering useful suggestions. The authors are also thankful to Prof. $R$ Vasudevan, Indian Institute of Technology, Madras, for the X-ray powder photographs, and to Dr D H Sastry, Indian Institute of Science, Bangalore, for the x-ray diffractograms. One of the authers (NSR) is thankful to University Grants Commission for awarding a fellowship.

\section{References}

Abdullah M I and Atherton M P 1964 Am. J. Sci. 262904

Akimoto S and Katsura T $1959 \mathrm{~J}$. Geomag. Geoelect. 1069

Akimoto S, Katsura T and Yoshida M $1957 \mathrm{~J}$. Geomag. Geoelect. 9165

Basta E Z 1957 Miner. Mag. 31431

Basta E Z 1959 Econ. Geol. 54698

Buddington A F, Fahey J and Vlusides A 1955 Am. J. Sci. 25493

Davis P M and Evans M E 1976 J. Geophys. Res. 81989

Day R, Fuller M D and Schmidt V A $1976 \mathrm{~J}$. Geophys. Res. 81783

Deutsch E R and Patzold R R 1976 J. Geophys, Res. 814188

Dunlop D J 1972 Science 17641

Dunlop D J, Hanes J A and Buchan K L 1973 J. Geophys. Res. 781387

Edwards A B 1949 Am. Mineral. 34759

Gjelsvik T 1957 Econ. Geol. 52482

Greig J W, Posnjak E, Merwin H E and Sasman R B 1935 Am. J. Sci. 30239

Joshima M 1973 Rockmagnetism and Palaeogeophysics 19

Kono M 1977 Rockmagnetism and Palaeogeophysics 418

Nagata T 1961 Rock magnetism (Tokyo: Maruzen Company Ltd.)

O'Reilly W and Banerjee S K 1967 Miner. Mag. 3629

O'Reilly W and Readman P W 1971 Z. Geophys. 37321

Ozima $M$ and Sakamoto N 1971 J. Geophys. Res. 767035

Radhakrishnamurty C 1975 Geophys. Res. Bull. NGRI 13135

Radhakrishnamurty C and Deutsch E R 1974 J. Geophys. 40453

Radhakrishnamurty C, Deutsch E R and Murthy G S 1979 J. Geophys. 45433

Radhakrishnamurty C and Likbite S D 1970 Earth Planet. Sci. Lett. 7389

Radhakrishnamurty C, Likhite S D, Deutsch E R and Murthy G S 1978 Proc. Indian Acad. Sci. (Earth Planet. Sci.) A87 235

Radhakrishnamurty C, Likhite S D and Sahasrabudhe P W 1977 Phys. Earth. Planet. Inter. 13289

Radhakrishnamurty C and Sastry N P 1970 Proc. Indian Acad. Sci. A72 94

Ramaswamy K and Ramamurthy N 1980 Proc. Indian Acad. Sci. (Earth Planet. Sci.) 89261

Stacey F D and Banerjee S K 1974 The Physical principles of rock magnerism (New York: Elsevier)

Tanaka $\mathrm{H}$ and Kono M 1974 Rock magnetism and Palaeogeophysics 221

Tarling D H 1971 Principles and application of palaeomagnetism (London: Chapman and Hall) 